\title{
DOKUMENTASI KEPERAWATAN dan HUBUNGAN PERILAKU PERAWAT DALAM PENDOKUMENTASIAN KEPERAWATAN
}

\author{
Cindy Minannisa \\ cindyminannisa01@gmail.com
}

\begin{abstract}
Abstrak
Dokumentasi keperawatan adalah Suatu dokumen atau catatan yang berisi data tentang keadaan pasien yang dilihat tidak saja dari tingkat kesakitan akan tetapi juga dilihat dari jenis, kualitas dan kuantitas dari layanan yang telah diberikan perawat dalam memenuhi kebutuhan pasien (Ali, 2010). Dokumentasi keperawatan merupakan aspek penting yang perlu ditingkatkan. Dokumentasi keperawatan menjadi salah satu fungsi yang paling penting dari perawat. Dokumentasi merupakan tanggung jawab dan tugas perawat setelah melakukan intervensi keperawatan. Pendokumentasian yang tidak lengkap dapat menurunkan mutu pelayanan keperawatan. Tujuan: untuk mengetahui apa itu dokumentasi dalam keperawatan dan bagaimana hubungan perilaku perawat dengan pendokumentasian asuhan keperawatan. Metode: Tugas ini menggunakan metode Literature review dimana dilakukan dengan cara menganalisis kajian dan eksplorasi jurnal, text book, maupun e-book yang relevan dan membahas tentang dokumentasi keperawatan dan hubungan perilaku perawat dalam pendokumentasian keperawatan. Hasil: Hasil dari pengkajian ini dengan menggunakan metode literatur review adalah dengan membaca pengkajian ini pembaca dapat melakukan dokumentasi dalam asuhan keperawatan dengan benar dan menjalankannya sesuai dengan ketetapan asuhan keperawatan dan mengetahui hubungan perilaku perawat dalam melakukan pendokumentasian keperawatan.
\end{abstract}

\section{Kata Kunci: Dokumentasi, Keperawatan, Rumah sakit}

\section{LATAR BELAKANG}

Asuhan keperawatan yang diberikan perawat kepada pasien dimulai dari memahami konsep dasar keperawatan tentang teori dari ilmu keperawatan kemudian melakukan pengkajian dan riwayat pasien, perencanaan yang terdiri dari (penegakan diagnosis keperawatan, penentuan target sasaran, dan perencanaan keperawatan), pelaksanaan, dan yang terakhir evaluasi atau penilaian yang berkelanjutan. Pendokumentasian merupakan unsur pokok dalam tugas dan 
tanggung jawab hukum setelah melakukan tindakan keperawatan kepada pasien. Dokumentasi keperawatan merupakan bukti tertulis pelayanan yang diberikan kepada pasien oleh tenaga keperawatan yang bertujuan untuk menghindari kesalahan, tumpang tindih dan ketidak lengkapan informasi.

Sejak zaman Florence Nightingale, perawat telah menganggap dokumentasi sebagai bagian yang vital dari praktik professional. Pada tulisan awalnya Nightingale menggambarkan tentang perlunya perawat untuk mencatat "penggunaan yang tepat dari udara segar, cahaya, kehangatan, kebersihan, serta pemilihan dan pemberian diet yang tepat," dengan tujuan mengumpulkan ,menyimpan dan mendapatkan kembali data untuk menatalaksanakan pasien secara cerdas (Camp, 2004).

Dalam asuhan keperawatan agar terbinanya koordinasi yang baik dan dinamis antar tenaga keperawatan serta meningkatkan efisiensi, efektifitas dan menjamin kualitas asuhan keperawatan. Undang-Undang RI Nomor 44 Tahun 2009 tentang Rumah Sakit Pasal 52 menyatakan bahwa setiap rumah sakit wajib melakukan pencatatan dan pelaporan semua penyelenggaraan kegiatan rumah sakit dalam bentuk sistim informasi manajemen berupa pencatatan, penyimpanan, pelaporan dan pemusnahan dalam waktu tertentu sesuai peraturan perundang-undangan.

Dokumentasi keperawatan merupakan suatu yang mutlak harus ada untuk perkembangan keperawatan khususnya proses profesionalisasi keperawatan serta mempertahankan keperawatan sebagai suatu profesi yang luhur dan terpandang di masyarakat. Dokumentasi keperawatan dalam bentuk dokumen asuhan keperawatan merupakan salah satu alat pembuktian atas tindakan perawat selama menjalankan tugas pelayanan keperawatan. Penyelenggaraan proses keperawatan terdiri dari pengkajian, diagnosa, perencanaan, implementasi dan evaluasi. Semua tindakan tersebut harus didokumentasikan sebagai bukti penyelenggaraan proses keperawatan. Data klinis yang lengkap dan berkualitas dapat meningkatkan mutu layanan kesehatan. Keengganan klinisi menulis secara lengkap setiap proses penatalaksanaan medis merupakan kendala yang dihadapi.

Pendokumentasian asuhan keperawatan dilakukan sebagai bukti tindakan keperawatan sudah dilakukan secara professional dan legal sehingga dapat memberikan perlindungan pada 
perawat dan pasien (Iyer \& Camp, 2005). Pendokumentasian berguna bagi rumah sakit dalam meningkatkan standar akreditasi, sebagai alat komunikasi antar profesi, indikator pelayanan mutu, bukti tanggung jawab, dan tanggung gugat perawat, sumber data dan sebagai sarana penelitian (Teytelman, 2002; Jefferies, Johnson, Nicholls \& Lad, 2012).

Perilaku adalah tindakan atau aktivitas dari manusia itu sendiri yang mempunyai bentangan yang sangat luas antara lain : berjalan, berbicara, menangis, tertawa, bekerja, kuliah, menulis, membaca, dan sebagainya. Sikap perawat merupakan salah satu elemen yang berpengaruh pada faktor predisposisi dan menjadi gambaran dari perilaku perawat dalam melaksanakan dokumentasi asuhan keperawatan. Proses keperawatan mengandung unsur-unsur yang bermanfaat bagi perawat dan klien. Perawat dan klien membutuhkan proses asuhan keperawatan, merencanakan, melaksanakan, dan menilai hasil dari asuhan keperawatan. Semua itu memerlukan pendokumentasian sehingga perawat mendapatkan data klien dengan sistematis. Perawat dan praktik keperawatan tergambar setiap hari bagi yang membaca catatan pasien. Data keperawatan yang terdapat dalam catatan merefleksikan standar asuhan keperawatan.dan anggota tim kesehatan lain membuat keputusan perawatan berdasarkan catatan keperawatan. Pencatatan telah dipandang sebagai riwayat sekunder untuk perawatan pasien.

\section{METODE}

Metode yang saya gunakan adalah Literature review dimana dilakukan dengan cara menganalisis kajian dan eksplorasi jurnal, text book, maupun e-book yang relevan dan membahas tentang dokumentasi keperawatan dan pengaruh perilaku perawat dalam pendekomentasian keperawatan. Dengan metode ini informasi pembahasan mengenai dokumentasi keperawatan dan pengaruh perilaku perawat dalam pendekomentasian keperawatan dapat dihami dan mempelajari bagaimana cara melakukan pendokumentasian dengan tepat sesuai dengan asuhan keperawatan. Sumber yang digunakan bersifat subjektif yaitu proses penulisan yang lebih fokus pada landasan teori. Dan melakukan analisis buku dan e-jurnal yang relevan dan berfokus kepada pengaplikasian berfikir kritis dalam mengelola informasi dan komunikasi keperawatan. Sumber yang digunakan adalah sumber yang diterbitkan di 8 tahun terakhir dan referensi akan dicantumkan dibagian daftar pustaka. 


\section{HASIL}

Dokumentasi merupakan bagian penting dari praktik keperawatan sebagai bentuk komunikasi efektif antar tenaga kesehatan professional lainnya. Proses pendokumentasian asuhan keperawatan dirumah sakit dapat dipengaruhi oleh faktor lingkungan rumah sakit dan dari faktor perawat. Dokumentasi merupakan salah satu sarana komunikasi antar petugas kesehatan dalam rangka pemulihan kesehatan klien. Perawat bertanggung jawab dan bertanggung gugat dalam pencatatan tindakan keperawatan. Tanpa dokumentasi yang benar dan jelas, kegiatan pelayanan keperawatan yang telah dilaksanakan oleh seorang perawat tidak dapat dipertanggung jawabkan dalam upaya peningkatan mutu pelayanan keperawatan dan perbaikan status kesehatan klien. Pelaksanaan dokumentasi keperawatan merupakan salah satu alat ukur untuk mengetahui, memantau, dan menilai suatu pelayanan asuhan keperawatan yang dilakukan oleh rumah sakit (Fischbach, 1991).

Dokumentasi keperawatan tidak hanya mencerminkan kualitas perawatan saja tetapi membuktikan pertanggunggugatan setiap tim keperawatan (Potter \& Perry, 2005). Oleh karena itu, jika kegiatan keperawatan tidak didokumentasikan dengan baik, akurat, obyektif, dan lengkap serta sesuai dengan standar asuhan keperawatan maka sulit untuk membuktikan bahwa tindakan keperawatan telah dilakukan dengan benar (Gillies, 2000; Carpenito, 1999). Pendokumentasian yang baik mempunyai ciri-ciri berdasarkan fakta, data yang akurat, kelengkapan, ringkas, terorganisasi, ketepatan waktu, mudah untuk dibaca. Dokumentasi asuhan keperawatan yang berkualitas harus terdapat unsur keakuratan, kelengkapan, dan kerelevananan. Kegiatan dokumentasi keperawatan yang tidak lengkap dalam pendokumentasian, keakuratan dan tidak relevan maka akan terjadi kesulitan dalam melakukan pembuktian tindakan yang sudah dilaksanakan dengan baik dan benar.

Pelayanan dan asuhan keperawatan terhadap pasien merupakan bentuk pelayanan profesional yang bertujuan untuk membantu pasien memulihkan dan meningkatkan kemampuan dirinya; tindakan perawat dilakukan secara komprehensif dan berkesinambungan (Gillies, 1990). Sikap perawat merupakan salah satu elemen yang berpengaruh pada faktor predisposisi dan menjadi gambaran dari perilaku perawat dalam melaksanakan dokumentasi asuhan keperawatan. Proses keperawatan mengandung unsur-unsur yang bermanfaat bagi perawat dan klien. Perawat dan klien membutuhkan proses asuhan keperawatan, merencanakan, melaksanakan, dan menilai 
hasil dari asuhan keperawatan. Semua itu memerlukan pendokumentasian sehingga perawat mendapatkan data klien dengan sistematis. Menurut Green dalam Notoatmodjo (2010) mengatakan bahwa sikap menentukan perilaku seseorang. Sikap yang positif diharapkan menjadi dorongan yang kuat dalam usaha melakukan pendokumentasian asuhan keperawatan dan perawat yang memiliki sikap yang negatif, perilakunya untuk pendokumentasian asuhan keperawatan kurang baik.

Sehingga dapat disimpulkan bahwa perilaku perawat yang baik dapat membuat dokumentasi asuhan keperawatan yang lengkap, dan juga dapat dikatakan bahwa jika seorang perawat yang memiliki perilaku yang kurang baik tidak memiliki atau membuat dokumentasi asuhan keperawatan yang lengkap.

\section{PEMBAHASAN}

\section{Pengertian dan Dasar Pelaksanaan Dokumentasi Keperawatan}

Dokumentasi keperawatan merupakan bukti pencatatan dan pelaporan yang dimiliki perawat dalam melakukan catatan keperawatan yang berguna untuk kepentingan klien, perawat dan tim kesehatan dalam memberikan pelayanan kesehatan. Dokumentasi merupakan tanggung jawab dan tugas perawat setelah melakukan intervensi keperawatan. Pendokumentasian yang tidak lengkap dapat menurunkan mutu pelayanan keperawatan.

Dokumentasi keperawatan merupakan bagian dari pelaksanaan asuhan keperawatan yang menggunakan pendekatan proses keperawatan yang memilliki nilai hukum yang sangat penting. Tanpa dokumentasi keperawatan maka semua implementasi keperawatan yang telah dilaksanakan oleh perawat tidak mempunyai makna dalam hal tanggung jawab dan tanggung gugat. Dokumentasi keperawatan dapat dikatakan sebagai "pegangan" bagi perawat dalam mempertanggung jawabkan dan membuktikan pekerjaannya. Oleh karena itu ada berbagai aturan dan kaidah yang harus ditaati oleh setiap perawat dalam melakukan pendokumentasian keperawatan. Dengan proses keperawatan, rasa tanggung jawab dan tanggung gugat bagi perawat itu dapat dimiliki dan dapat digunakan dalam tindakan-tindakan yang merugikan atau menghindari tindakan yang legal. Semua tatanan perawatan kesehatan secara hukum perlu mencatat observasi keperawatan. 
Potter (2005) mendefenisikan dokumentasi sebagai segala sesuatu yang tercetak atau tertulis yang dapat diandalkan sebagai catatan tentang bukti bagi individu yang berwenang. Dokumentasi keperawatan juga merupakan salah satu bentuk upaya membina dan mempertahankan akontabilitas perawat dan keperawatan. Pelaksanaan dokumentasi proses keperawatan juga sebagai salah satu alat ukur untuk mengetahui, memantau dan menyimpulkan suatu pelayanan asuhan keperawatan yang diselenggarakan di rumah sakit. Dokumentasi keperawatan adalah bukti pencatatan perawat dalam melakukan asuhan keperawatan yang disusun secara sistematis dalam suatu format yg dapat dipertanggung jawabkan secara hukum.

Dokumentasi keperawatan terdiri dari 1) keterampilan berkomunikasi untuk pengumpulan data dan menciptakan hubungan baik antara perawat dan klien dalam pemecahan masalah klien. 2) dokumentasi proses keperawatan yang merupakan metode pemecahan masalah secara sistimatis sesuai kaidah keperawatan dan 3) standar dokumentasi dapat memberi informasi pernyataan kualitas dan kuantitas dokumentasi untuk memperkuat pola pendokumentasian keperawatan.

Penerapan kompetensi proses keperawatan di lahan klinik dapat dinilai dari pencatatan dan pelaporan yang dituliskan dalam bentuk pendokumentasian asuhan keperawatan yang secara keseluruhan setiap tahapannya dikenal dengan tahapan proses keperawatan. Disisi lain pendokumentasian asuhan keperawatan merupakan bukti fisik aktivitas atau kinerja perawat dalam bentuk data administrasi yang mutlak harus ada karena memiliki banyak manfaat.

\section{Manfaat Manfaat dokumentasi}

Dokumentasi keperawatan mempunyai makna yang penting dalam berbagai aspek, yaitu aspek kualitas pelayanan karena pendokumentasian memberi kemudahan dalam memberikan pelayanan dan penyelesaian masalah klien sebagai acuan evaluasi untuk meningkatkan mutu pelayanan, aspek komunikasi dan sebagai sarana komunikasi antara perawat dengan klien atau keluarga, tenaga kesehatan lain sehingga dapat membentuk suatu koordinasi yang baik dan tidak terjadi duplikasi yang tidak efektif dan efisien, aspek hukum sebagai dokumen resmi dan bernilai hukum atau legalitas dalam sistem pelayanan keperawatan sehingga apabila terjadi suatu masalah hukum maka dokumentasi dapat dijadikan sebagai barang bukti di pengadilan, aspek pendidikan dan pelatihan dokumentasi mempunyai nilai pendidikan karena isinya menyangkut kronologis dari kegiatan asuhan keperawatan yang dapat dijadikan sebagai referensi 
pembelajaran bagi peserta didik profesi keperawatan, aspek keuangan semua asuhan keperawatan yang belum, sedang atau telah diberikan didokumentasikan yang dapat dijadikan acuan atau pertimbangan biaya bagi klien, aspek penelitian dapat dijadikan sebagai bahan atau objek riset dan pengembangan profesi keperawatan,aspek akreditasi pendokumentasian asuhan keperawatan sebagai indikator dalam penilaian suatu pelayanan keperawatan dalam akreditasi rumah sakit (Nursalam,2007).

Salah satu manfaat dari pendokumentasian asuhan keperawatan adalah menunjukan profesionalisme perawat di tatanan pelayanan klinis. Menurut Potter dan Perry (2005), dokumentasi merupakan segala sesuatu yang tertulis atau tercetak yang dapat diandalkan sebagai catatan tentang bukti individu.

\section{Prinsip Dokumentasi Keperawatan}

Dokumentasi kepeawatan mempunyai 3 prinsip yaitu: Brevity, Legibility, dan Accuraey. Prinsip-prinsip tersebut di atas dapat dijelaskan sebagai berikut:

a. Brevity

Dalam melakukan pendokumentasian setiap petugas/perawat harus brevity, Brevity sendiri adalah ringkas, jadi kita dalam mencatat isi dokumentasi keperawatan harus ringkas dan tidak perlu memasukan kata;kata atau kalimat yang tidak penting dan mempunyai makna yang tidak sesuai. Misal :

- Intervensi: Berikan cairan infus RL 4 tetes/menit (ringkas/brevity)

- Intervensi: Berikan cairan infus ringer laktat 4 tetes per menit karena di sarankan oleh dokter bedah yaitu dr. AA Sp.D. yang jaga sihf pagi. ( tidak brevity).

Dengan menuliskan catatatan yang ringkas dan mengenai inti masalah maka catatan dokumentasi akan mudah di pahami dan tidak memakan ruang dalam lembar yang tersedia.

b. Legidibility Legidibility yaitu dimana dalam penulisan/pencatatan dokumentasi keperawatan harus mudah dibaca dan di pahami oleh perawat lain atau profesi lain yang ikut dalam proses pendokumentasian. Misal :

- Perawat harus menuliskan catatan yang jelas yang bisa dibaca dan di mengerti oleh perawat lain, dan tidak menuliskan istilahistilah yang tidak di pahami 
oleh orang lain. Semisal ada istilah baru maka harus segera di diskusikan ke semua tim untuk menggunakan istilah tersebut.

c. Accuracy Accuracy adalah sesuai dengan data yang ada pada klien. Jadi kita harus memasukan data pada dokementasi keperawatan harus benar dan sesuai dengan data baik identitas, laboratorium dan radiologi pada setiap klien. Ini adalah aspek yang sangat vital dan tidak boleh salah atau tertukar dengan klien lain. Misal : Dalam memasukan data pemberian obat perawat harus teliti dan tidak boleh salah, obat yang resepkan untuk Tn. A tidak boleh di berikan kepada Tn. C. Adapun prisip-prinsip dalam melakukan dokumentasi yang alain yaitu:

- Dokumen merupakan suatu bagian integral dari pemberian asuhan keperawatan.

- Praktik dokumentasi bersifat konsisten.

- Tersedianya format dalam praktik dokumentasi.

- Dokumentasi hanya dibuat oleh orang yang melakukan tindakan atau mengobservasi langsung klien.

- Dokumentasi harus dibuat sesegera mungkin.

- Catatan harus dibuat secara kronologis. g. Penulisan singkatan harus menggunakan istilah yang sudah berlaku umum dan seragam.

- Tuliskan tanggal, jam, tanda tangan, dan inisial penulis.

- Catatan harus akurat, benar, komplit, jelas, ringkas, dapat dibaca, dan ditulis dengan tinta.

- Dokumentasi adalah rahasia dan harus disimpan dengan benar.

\section{Hubungan Perilaku Perawat dalam Pendokumentasian Keperawatan}

Dokumentasi merupakan salah satu sarana komunikasi antar petugas kesehatan dalam rangka pemulihan kesehatan klien. Perawat bertanggung jawab dan bertanggung gugat dalam pencatatan tindakan keperawatan. Tanpa dokumentasi yang benar dan jelas, kegiatan pelayanan keperawatan yang telah dilaksanakan oleh seorang perawat tidak dapat dipertanggungjawabkan dalam upaya peningkatan mutu pelayanan keperawatan dan perbaikan status kesehatan klien.

Dokumentasi yang baik mencerminkan kwalitas perawatan dan yang membuktikan mempertanggunggugatan setiap anggota tim perawatan dalam memberikan asuhan keperawatan pada klien. Sistem dokumentasi yang ideal harus memberikan informasi klien yang 
komprehensif, dokumen legal (Twardon \& Gartner,1993) dalam Potter \& Perry (2005). Pendokumentasian asuhan keperawatan merupakan aspek legal yang dapat dijadikan standar ataupun tolak ukur dalam pemberian asuhan keperawatan di sebuah rumah sakit.

Dokumentasi keperawatan merupakan bukti pencatatan dan pelaporan yang dimiliki perawat dalam melakukan catatan perawatan yang berguna untuk kepentingan klien, perawat, dan tim kesehatan dalam memberikan pelayanan kesehatan dengan dasar komunikasi yang akurat dan lengkap secara tertulis dengan tanggung jawab perawat (Camp, 2004). Dokumentasi ini penting karena pelayanan keperawatan yang diberikan pada klien membutuhkan catatan dan pelaporan yang dapat digunakan sebagai tanggung jawab dan tanggung gugat dari berbagai kemungkinan masalah yang dialami klien baik masalah kepuasan maupun ketidak puasan terhadap pelayanan yang diberikan. (Nursalam, 2008).

Menurut Notoatmodjo, (2007) Perilaku adalah tindakan atau aktivitas dari manusia itu sendiri yang mempunyai bentangan yang sangat luas antara lain : berjalan, berbicara, menangis, tertawa, bekerja, kuliah, menulis, membaca, dan sebagainya. Dari uraian ini dapat disimpulkan bahwa yang dimaksud perilaku manusia adalah semua kegiatan atau aktivitas manusia, baik yang diamati langsung, maupun yang tidak dapat diamati oleh pihak luar.

Sikap perawat merupakan salah satu elemen yang berpengaruh pada faktor predisposisi dan menjadi gambaran dari perilaku perawat dalam melaksanakan dokumentasi asuhan keperawatan. Proses keperawatan mengandung unsur-unsur yang bermanfaat bagi perawat dan klien. Perawat dan klien membutuhkan proses asuhan keperawatan, merencanakan, melaksanakan, dan menilai hasil dari asuhan keperawatan. Semua itu memerlukan pendokumentasian sehingga perawat mendapatkan data klien dengan sistematis (Hidayat, 2000). Menurut Potter \& Perry (2005), sebagai anggota dari tim perawatan kesehatan, perawat harus mengkomunikasikan informasi tentang klien secara akurat. Kualitas perawatan klien bergantung pada kemampuan pemberi perawatan untuk berkomunikasi satu sama lain.

Proses dokumentasi keperawatan dalam bidang gawat darurat memiliki fokus berbeda pada tahap pengkajian karena terkait kondisi akut pasien atau kegawat daruratan yang mengancam nyawa (lyer, 2004; Asmadi, 2008). Seluruh data yang diperlukan untuk mengidentifikasi masalah keperawatan klien dicatatat dengan terperinci. Data yang terkumpul harus lengkap, guna membantu mengatasi masalah klien yang adekuat, akurat dan nyata 
(Potter\&Perry, 2011). Kuehl (2005), menambahkan kualitas perawat dari potensial gugatan malpraktik.

Perawat IGD menyadari dokumentasi keperawatan yang dibuat harus menggambarkan masalah yang dialami pasien, karena asuhan keperawatan yang diberikan bertujuan mengatasi masalah pasien. Oleh karena itu, akurasi atau ketepatan data pada saat pengkajian sangat diperlukan agar sesuai dengan masalah pasien yang sebenarnya. Hasil penelitian Eeden (2009) bahwa dokumentasi keperawatan dalam praktik keperawatan aka membantu kebutuhan perawatan kesehatan pasien.

Berdasarkan hasil penelitian menunjukkan bahwa intensi perawat dalam pendokumentasian asuhan keperawatan memiliki hubungan signifikan terhadap perilaku perawat dalam pendokumentasian asuhan keperawatan. Hubungan ini dapat diprediksi bahwa intensi sebagai factor motivasional yang menentukan seorang melakukan pendokumentasian asuhan keperawatan dan mengidintifasikan seberapa kuat keyakinan seseorang akan menerapkan suatu perilaku dan seberapa besar usaha yang akan digunakan untuk melakukan perilaku tersebut.

Perilaku perawat dalam menyikapi proses dokumentasi dapat mempengaruhi kredibilitas dokumentasi keperawatan. Kualitas perilaku perawat seperti semangat, komitmen, dan kepedulian perawat dalam melaksanakan dokumentasi keperawatan lebih sulit untuk diketahui secara obyektif, perilaku tersebut cenderung bisa diketahui dari penulisan dokumentasi yang lengkap sehingga terdapat gambaran perilaku perawat selama proses keperawatan. Perilaku perawat juga dapat dipengaruhi oleh faktor tingkat pengalaman kerja, motivasi kerja, dan pengalaman kerja dalam penulisan dokumentasi yang lebih efektif, mendetail, dan mudah dimengerti oleh antar profesi kesehatan professional. Berdasarkan penelitian yang dilakukan oleh Josua Edison Mangole pada tahun 2015 menunjukan bahwa perilaku yang baik dengan pendokumentasian yang lengkap sebanyak (66\%) dan responden yang memiliki perilaku baik dengan pendokumentasian tidak lengkap sebanyak (33,3\%), perilaku kurang baik dengan pendokumentasian lengkap sebanyak (20\%) dan pendokumentasian yang tidak lengkap sebanyak (80\%). Bahwa hasil dari penelitian tersebut terdapat hubungan yang signifikan antara perilaku perawat dengan pendokumentasian asuhan keperawatan. 


\section{PENUTUP}

Keperawatan adalah bentuk pelayanan profesional berupa pemenuhan kebutuhan dasar yang diberikan kepada individu yang sehat maupun sakit yang mengalami gangguan fisik, psikis, dan sosial agar dapat mencapai derajat kesehatan yang optimal. Bentuk pemenuhan dasar dapat berupa meningkatkan kemampuan yang ada pada individu, mencegah, memperbaiki, dan melakukan rehabilitasi dari suatu keadaan yang dipersepsikan sakit oleh individu (Alligood \& Tomey,2006). Dokumentasi merupakan tanggung jawab dan tugas perawat setelah melakukan intervensi keperawatan. Menurut teori hakikat dokumentasi asuhan keperawatan adalah terciptanya kegiatankegiatan keperawatan yang menjamin tumbuhnya pandangan, sikap, cara berpikir, dan bertindak profesional pada setiap perawat.

Dokumentasi keperawatan merupakan suatu yang mutlak harus ada untuk perkembangan keperawatan khususnya proses profesionalisasi keperawatan serta mempertahankan keperawatan sebagai suatu profesi yang luhur dan terpandang di masyarakat, karena dengan dokumentasi dapat tercermin mutu suatu asuhan keperawatan yang diberikan. Dokumentasi asuhan keperawatan mencakup pernyataan dan pelaporan tentang pengkajian (pengumpulan data), diagnosis keperawatan, rencana tindakan keperawatan, tindakan dan evaluasi keperawatan. Dokumentasi yang efektif menjamin kesinambungan pelayanan, menghemat waktu, dan meminimalisasi resiko kesalahan (Potter \& Perry, 2009). Hal ini menyebabkan masalah penting bagi praktisi keperawatan dalam pendokumentasian asuhan keperawatan kepada pasien. Perawat dan praktik keperawatan tergambar setiap hari bagi yang membaca catatan pasien. Data keperawatan yang terdapat dalam catatan merefleksikan standar asuhan keperawatan.dan anggota tim kesehatan lain membuat keputusan perawatan berdasarkan catatan keperawatan. Pencatatan telah dipandang sebagai riwayat sekunder untuk perawatan pasien.

\section{DAFTAR PUSTAKA}

Dewi Rosmalia, R. M. (2015). Analisis Sistim Manajemen Dokumentasi Keperawatan pada Poliklinik Gigi Rumah Sakit di Bukittinggi. Jurnal Kesehatan Andalas, 4(3), 967-972.

Dyah Fitri Wulandari, H. H. (2019, Juni). PENGEMBANGAN DOKUMENTASI KEPERAWATAN BERBASIS ELEKTRONIK DI RS X KOTA DEPOK DENGAN 
MENGGUNAKAN TEORI PERUBAHAN LEWINS. Jurnal Keperawatan Global, 4(1), $55-64$.

Hasmawati, S. W. (2020). Hubungan Antara Motivasi dengan Perilaku Perawat dalam Mendokumentasikan Asuhan Keperawatan di Instalasi Rawat Inap RSUD Wates Kulon Progo. Indonesian Journal of Hospital Administration, 3(1), 45-52.

Josua Edison Mangole, S. R. (2015, Oktober). HUBUNGAN PERILAKU PERAWAT DENGAN PENDOKUMENTASIAN ASUHAN KEPERAWATAN DI CARDIOVASKULAR AND BRAIN CENTER RSUP PROF. DR. R. D. KANDOU MANADO. E-journal Keperawatan (e-Kp), 3(2), 1-9.

Muryani, E. P. (2019). KUALITAS PENDOKUMENTASIAN ASUHAN KEPERAWATAN DI RUANG RAWAT INAP (Studi di RSUD Kalimantan Tengah). Nerspedia, 2(1), 27-32.

Noorkasiani, G. R. (2015, Maret). FAKTOR-FAKTOR YANG BERHUBUNGAN DENGAN KELENGKAPAN DOKUMENTASI KEPERAWATAN. Jurnal Keperawatan Indonesia, 18(1), 1-8.

Putri Wulandini. S., T. K. (2016, Oktober). FAKTOR-FAKTOR YANG BERHUBUNGAN DENGAN PENDOKUMENTASIAN ASUHAN KEPERAWATAN DI RUMAH SAKIT JIWA. NERS JURNAL KEPERAWATAN, 12(2), 131-142.

Rezkiki, F., \& Ilfa, A. (2018). Pengaruh Supervisi Terhadap Kelengkapan Dokumentasi Asuhan Keperawatan Di Ruangan Non Bedah. Real in Nursing Journal, 1(2), 67-76.

Rosari Tarigan, H. H. (2019). Manfaat Implementasi Dokumentasi Asuhan Keperawatan Berbasis Komputerisasi Dalam Meningkatkan Mutu Asuhan Keperawatan. Jurnal Ilmiah Kesehatan Pencerah, 8(2), 110-116.

Simamora, R. (2009). Dokumentasi Proses Keperawatan.

Simamora, R. H., Purba, J. M., Bukit, E. K., \& Nurbaiti, N. (2019). Penguatan Peran Perawat Dalam Pelaksanaan Asuhan Keperawatan Melalui Pelatihan Layanan Prima. JPPM (Jurnal Pengabdian Dan Pemberdayaan Masyarakat), 3(1), 25-31. 
Yeni, F. (2014). Pengaruh Pelatihan Proses Keperawatan terhadap Dokumentasi Asuhan Keperawatan di Puskesmas Kabupaten Agam Propinsi Sumatera Barat. NERS Jurnal Keperawatan, 10(1), 24-31.

Yustiana Olfah, A. G. (2016). DOKUMENTASI KEPERAWATAN. Jakarta: Pusat SDM Kesehatan. 